Acta vet. scand. $1981,22,260-271$.

From the Department of Internal Medicine I, Veterinary College of Norway, Oslo.

\title{
CONCENTRATION OF SERUM TRANSFERRIN IN SICK HORSES AND ITS RELATIONSHIP TO SERUM ALBUMIN CONTENT
}

\author{
By
}

Nils $E k$

\begin{abstract}
EK, NILS: Concentration of serum transferrin in sick horses and its relationship to serum albumin content. Acta vet. scand. 1981, 22, $260-271$. - Studies of transferrin (Tf) concentration in sera of sick horses were carried out using Mancini's immunodiffusion technique. Relative values against a chosen reference serum were determined for a total of 112 horses.

Horses with acute infections had Tf values significantly below the normal. The lowest individual $\mathrm{Tf}$ value in this group $(46 \%)$ was found in a six-months-old foal with temperature $41^{\circ} \mathrm{C}$ and watery diarrhoea.

Horses suffering from acute laminitis also had decreased $T f$ values. The lowest value in the whole material $(45 \%)$ was found in a horse belonging to this group.

There was a positive correlation between the $\mathrm{Tf}$ value and the albumin content in serum.

horse; serum transferrin concentration; diseases.

Quantification of transferrin in horse sera revealed significant differences between transferrin (Tf) phenotypes ( $E k$ 1981). The average $\mathrm{Tf}$ concentration was significantly higher in the $\mathrm{Tf}$ phenotypes DD, FF and $\mathrm{HH}$ when compared to the Tf phenotypes $\mathrm{OO}$ and RR. Furthermore, the average $\mathrm{Tf}$ concentration was significantly higher in foals than in mares.

In humans, low levels of plasma Tf concentration are associated with many diseases, in most of which there is also concurrent albumin depletion (Giblett 1969).

The purpose of the work reported in the present article was to investigate the possible effect of diseases on serum Tf concentration in horses, and to correlate the serum $\mathrm{Tf}$ concentration to the serum albumin content.
\end{abstract}




\section{MATERIALS AND METHODS}

The investigations were carried out on 112 horses, hospitalized at the Department of Internal Medicine I, Veterinary College of Norway. The material consisted of 105 horses aged 2 to 20 years, comprising 40 Warmblood Trotters, 47 Norwegian Trotters, 7 horses of mixed breeds, 4 Norwegian Fjordhorses, 2 Nordland horses, 1 New Forest pony, 1 English Hunter, 1 English Thoroughbred horse, 1 Iceland horse and 1 Shetland pony. In addition there were $5 \mathrm{~W}$ armblood Trotter foals and 2 Norwegian Trotter foals aged 10 days to 12 months.

The material was divided into 7 disease groups as will be seen under Results. Within disease groups subdivisions were made according to $\mathrm{Tf}$ phenotypes.

Tf values of TfD, TfF and TfH homozygotes and heterozygotes comprise one group whereas TfO and TfR homozygotes and heterozygotes comprise another. A third group consists of heterozygotes where TfD, TfF or TfH alleles occurred together with TfO or TfR alleles.

The horses were bled when they arrived at the clinic. Serum was pipetted off and stored at $-20^{\circ} \mathrm{C}$ when not used immediately.

Determination of $\mathrm{Tf}$ phenotypes and quantification of the transferrin was carried out as previously described ( $E k$ 1981).

The serum from a TfRR horse which was chosen as a reference serum was the same as in an earlier work ( $E k$ 1981). The quantity of transferrin of this horse was given the value of 100 per cent.

All quantification tests were carried out in duplicate. The precision of the method was determined as described in an earlier paper ( $E k$ 1981). The standard deviation of results of duplicate analyses of all samples was $\pm \mathbf{1 . 9}$.

The albumin percentage in serum was determined by electrophoresis on cellulose acetate membrane by the method described by $E k(1970)$. Total protein in the samples was determined using a refractometer (Bausch \& Lomb Serum Protein Meter).

Standard methods were employed for the statistical calculations. (Snedecor \& Cochran 1967).

\section{RESULTS}

Group I. Twentyseven horses with acute infections

The horses in this group were patients with a history of disease running a rapid course and with clinical signs of an 
acute infection (fever, pain and functional disturbance of the diseased organ). Post-mortem examination was carried out on 4 horses.

Table 1. Transferrin concentration and albumin content in serum of 27 horses with acute infections (Group I). For the transferrin quantifications the serum of a TfRR horse was chosen as a reference serum.

Correspondent values are given for the other disease groups.

Adult

'Transferrin

percentage

Albumin $\mathrm{g} / 100 \mathrm{ml}$

Tf phenotypes with Tf alleles $D, F$ and $H$

$\begin{array}{lcc}\text { Number } & 8 & 7 \\ \text { Range } & 73-110 & 1.7-3.5 \\ \text { Mean } & 96.4 & 2.6 \\ \text { Normal } & 105-154 & 2.8-3.5\end{array}$

(Compared with 30 healthy mares TfFF)

Tf phenotypes with Tf alleles $O$ and $R$

$\begin{array}{lcc}\text { Number } & 5 & 5 \\ \text { Range } & 52-64 & 1.5-3.3 \\ \text { Mean } & 59.6 & 2.4 \\ \text { Normal } & 64-93 & 2.8-3.5\end{array}$

(Compared with 29 healthy mares TfRR)

Tf heterozygotes with Tf alleles

$\mathrm{D}, \mathrm{F}$ or $\mathrm{H}$ combined with $\mathrm{O}$ or $\mathrm{R}$

$\begin{array}{lcc}\text { Number } & 10 & 10 \\ \text { Range } & 52-88 & 1.6-3.1 \\ \text { Mean } & 69.9 & 2.5 \\ \text { Normal } & 70-90 & 2.8-3.5\end{array}$

(Compared with 30 healthy mares TfFR)

Foals

Tf phenotypes with Tf alleles $D, F$ and $H$

$\begin{array}{lcc}\text { Number } & 3 & 3 \\ \text { Range } & 118-122 & 2.2-2.5 \\ \text { Mean } & 120 & 2.3 \\ \text { Normal } & 117-171 & 2.8-3.5\end{array}$

Tf heterozygotes with Tf alleles

$D, F$ or $\mathrm{H}$ combined with $\mathrm{O}$ or $\mathrm{R}$

$\begin{array}{lcc}\text { Number } & 1 & 1 \\ \text { Result } & 46 & 1.5 \\ \text { Normal } & 102-128 & 2.8-3.5\end{array}$


Table I shows that the Tf values in all Tf phenotype classes of adult horses were significantly lower than the corresponding values found in healthy horses. The lowest mean value was found in Tf phenotypes with TfO and TfR alleles. In foals there were few animals only, but the Tf values were decreased compared with those of healthy foals. The mean albumin values were below the normal range given by Kaneko \& Cornelius (1970).

The lowest Tf value in Group I was found in a male Norwegian Trotter foal aged 6 months. The foal had been sick for one week with fever and diarrhoea. The clinical signs were depression, temperature of $41.0^{\circ} \mathrm{C}$ and watery diarrhoea. The foal (TfFR) had a Tf value of $46 \%$ and albumin $1.5 \mathrm{~g}$ per $100 \mathrm{ml}$. The foal was treated daily with antibiotics and electrolytes and made steady improvement. It was discharged after 4 weeks as clinically improved.

\section{Group II. Seven horses with acute laminitis}

The animals in this group were horses with a history of an acute disease and clinical signs characteristic of acute laminitis such as severe pain in the feet, rapid pulse and respiration and reluctance to move. One postmortem examination was performed

T a b l e 2. Horses with acute laminitis (Group II).

\begin{tabular}{lll}
\hline Adult & $\begin{array}{c}\text { Transferrin } \\
\text { percentage }\end{array}$ & $\begin{array}{l}\text { Albumin } \\
\mathrm{g} / \mathbf{1 0 0} \mathrm{ml}\end{array}$ \\
\cline { 2 - 3 }
\end{tabular}

Tf phenotypes with Tf alleles $D, F$ and $H$

$\begin{array}{lcc}\text { Number } & 1 & 1 \\ \text { Result } & 75 & 2.6 \\ \text { Normal } & 105-154 & 2.8-3.5\end{array}$

Tf phenotypes with Tf alleles $O$ and $R$

$\begin{array}{lcc}\text { Number } & 1 & 1 \\ \text { Result } & 64 & 2.2 \\ \text { Normal } & 64-93 & 2.8-3.5\end{array}$

Tf heterozygotes with Tf alleles

$D, F$ or $\mathrm{H}$ combined with $\mathrm{O}$ or $\mathrm{R}$

$\begin{array}{lcc}\text { Number } & 5 & 5 \\ \text { Range } & 45-70 & 2.5-2.9 \\ \text { Mean } & 58.8 & 2.7 \\ \text { Normal } & 70-90 & 2.8-3.5\end{array}$

(Compared with 30 healthy mares TfFR) 
in this group. Table 2 shows that the Tf values in this disease group were decreased as compared with corresponding values in healthy horses. In the Tf phenotype class with heterozygotes (D, F or $\mathrm{H}$ alleles combined with $\mathrm{O}$ or $\mathrm{R}$ alleles) the decrease was highly significant. The albumin values were also decreased.

The patient having the lowest $T f$ value in the whole material was a 20-year-old Norwegian Trotter mare with a history of scratching and dry, scaly skin which had lasted for several weeks. The day before the arrival to the clinic the horse also showed severe lameness and had difficulties in moving. The clinical signs on admittance were a temperature of $39.0^{\circ} \mathrm{C}$, reluctance to walk and pulsation in the digital arteries. The skin was dry, scaly and partly crusted. The horse (TfFR) had a Tf value of $45 \%$ and albumin $2.7 \mathrm{~g}$ per $100 \mathrm{ml}$. The horse made no improvement and was destroyed after 10 days. Post-mortem report: Chronic superficial dermatitis and perivasculitis in corium.

Group III. Twentytwo horses with chronic obstructive pulmonary disease (COPD)

This group included horses with confirmed chronic disease of the lungs. These animals exhibited a variety of clinical respi-

T a b l e 3. Horses with chronic obstructive pulmonary disease (Group III).

\begin{tabular}{|c|c|c|}
\hline Adult & $\begin{array}{l}\text { Transferrin } \\
\text { percentage }\end{array}$ & $\begin{array}{l}\text { Albumin } \\
\mathrm{g} / 100 \mathrm{ml}\end{array}$ \\
\hline \multicolumn{3}{|c|}{ Tf phenotypes with Tf alleles $D, F$ and $H$} \\
\hline Number & 9 & 9 \\
\hline Range & $98-154$ & $2.8-3.5$ \\
\hline Mean & 117.6 & 3.2 \\
\hline Normal & $105-154$ & $2.8-3.5$ \\
\hline \multicolumn{3}{|c|}{ Tf phenotypes with Tf alleles $O$ and $R$} \\
\hline Number & 4 & 4 \\
\hline Range & $64-81$ & $2.8-3.6$ \\
\hline Mean & 75.5 & 3.3 \\
\hline Normal & $64-93$ & $2.8-3.5$ \\
\hline \multicolumn{3}{|c|}{ Tf heterozygotes with $\mathrm{Tf}$ alleles } \\
\hline Number & 9 & 9 \\
\hline Range & $67-92$ & $3.1-3.8$ \\
\hline Mean & 80.8 & 3.3 \\
\hline Normal & 70-90 & 2.8-3.5 \\
\hline
\end{tabular}


ratory abnormalities resulting in a chronic pulmonary dysfunction. The diagnosis was made on the basis of clinical examination and case history. The horses were not examined at postmortem.

All mean values (Table 3) were within the normal range for healthy horses with corresponding Tf phenotypes.

\section{Group IV. Nine horses with chronic enteritis}

The horses in this group were animals exhibiting signs of enteritis (diarrhoea) which had lasted for more than one week. No post-mortem examinations were performed. The results for this group are presented in Table 4 . All the mean Tf values in this group were close to the lower limit of the normal range.

T a b l e 4. Horses with chronic enteritis (Group IV).

\begin{tabular}{llcc}
\hline Adult & $\begin{array}{c}\text { Transferrin } \\
\text { percentage }\end{array}$ & $\begin{array}{c}\text { Alhumin } \\
\text { R/100 ml }\end{array}$ \\
\cline { 2 - 3 } Tf phenotypes with Tf alleles & $\mathrm{D}, \mathrm{F}$ and $\mathrm{H}$ & \\
Number & 1 & 1 \\
Result & 104 & 2.8 \\
Normal & $105-154$ & $2.8-3.5$ \\
\hline
\end{tabular}

Tf heterozygotes with Tf alleles

$D, F$ or $\mathrm{H}$ combined with $\mathrm{O}$ or $\mathrm{R}$

$\begin{array}{lcc}\text { Number } & 5 & 5 \\ \text { Range } & 60-96 & 2.9-3.6 \\ \text { Mean } & 73.4 & 3.3 \\ \text { Normal } & 70-90 & 2.8-3.5\end{array}$

(Compared with 30 healthy mares TfFR)

Foals

Tf heterozygotes with Tf alleles

$\mathrm{D}, \mathrm{F}$ or $\mathrm{H}$ combined with $\mathrm{O}$ or $\mathrm{R}$

$\begin{array}{lcc}\text { Number } & 3 & 3 \\ \text { Range } & 80-133 & 2.7-3.0 \\ \text { Mean } & 104.3 & 2.9 \\ \text { Normal } & 102-128 & 2.8-3.5\end{array}$

Group V. Five horses with malignant tumours

This group consisted of horses suffering from different malignant tumours. Diagnosis was based on clinical signs and postmortem examination.

Results are shown in Table 5. The Tf values from the two patients in the first Tf phenotype class in Table 5 were close to 
the mean value found in healthy horses. In the second class one horse had a Tf value of $50 \%$ only, whereas the two others showed increased Tf values (both $122 \%$ ) compared with values of healthy animals. The horse with the low Tf value was a Norwegian Trotter gelding, 15 years old (TfFR) with a severe monoclonal hypergamma-globulinaemia. The post-mortem diagnosis was: Lymphosarcoma in the liver, the kidneys, the myocardium and the lymph nodes. The case is described in an earlier paper (Ek 1980).

T a b l e 5. Horses with malignant tumours (Group V).

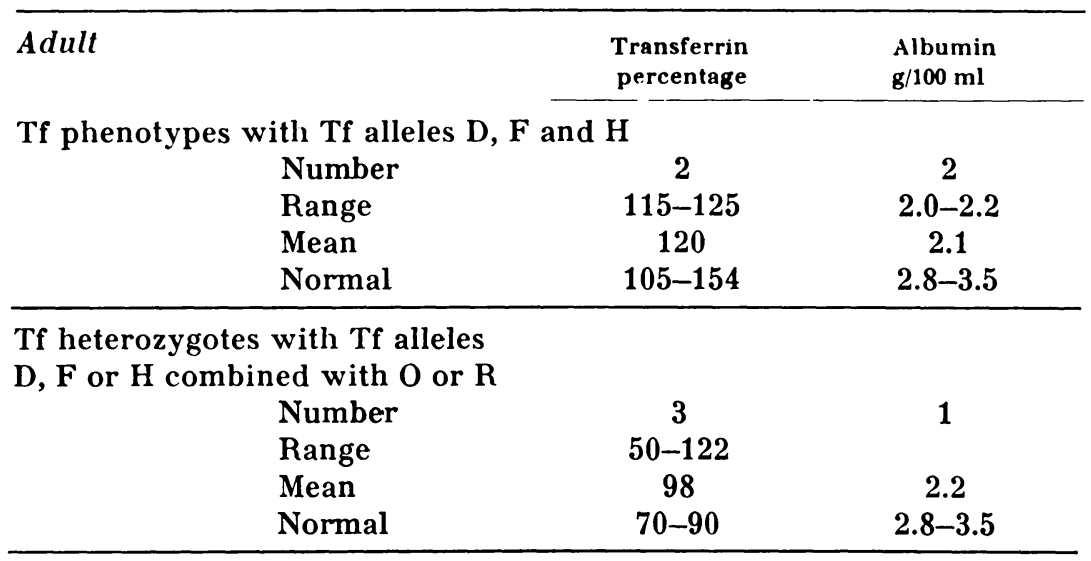

Group VI. Thirteen horses with colic

This group was composed of horses exhibiting abdominal pain associated with different diseases of the abdominal viscera

T a b l e 6. Horses with colic (Group VI).

\begin{tabular}{lll}
\hline Adult & $\begin{array}{c}\text { Transferrin } \\
\text { percentage }\end{array}$ & $\begin{array}{c}\text { Albumin } \\
\mathbf{g} / 100 \mathrm{ml}\end{array}$ \\
\hline
\end{tabular}

Tf phenotypes with Tf alleles $\mathrm{D}, \mathrm{F}$ and $\mathrm{H}$

$\begin{array}{lcc}\text { Number } & 11 & 11 \\ \text { Range } & 108-138 & 3.1-3.9 \\ \text { Mean } & 120.1 & 3.5 \\ \text { Normal } & 105-154 & 2.8-3.5\end{array}$

Tf heterozygotes with $\mathrm{Tf}$ alleles

$\mathrm{D}, \mathrm{F}$ or $\mathrm{H}$ combined with $\mathrm{O}$ or $\mathrm{R}$

\begin{tabular}{lcc} 
Number & 2 & 2 \\
Range & $65-104$ & $2.5-2.9$ \\
Mean & 84.5 & 2.7 \\
Normal & $70-90$ & $2.8-3.5$ \\
\hline
\end{tabular}


such as intestinal impaction and intestinal tympany. Post-mortem examination was carried out on 3 horses. The mean Tf values in this group (Table 6) were within normal range.

Group VIL. Twentynine horses with organic diseases

This group comprised horses which were suffering from different organic conditions not associated with inflammatory reactions (myopathy, arthrosis, eczema etc.). No post-mortem examinations were carried out.

Results are shown in Table 7 . All the mean values were within normal range.

T a b l e 7. Horses with organic diseases (Group VII).

\begin{tabular}{lll}
\hline Adult & $\begin{array}{c}\text { Transferrin } \\
\text { percentage }\end{array}$ & $\begin{array}{c}\text { Albumin } \\
\text { g/100 ml }\end{array}$ \\
\hline
\end{tabular}

Tf phenotypes with Tf alleles $D, F$ and $H$

$\begin{array}{lcc}\text { Number } & 13 & 13 \\ \text { Range } & 85-176 & 1.7-3.7 \\ \text { Mean } & 111.9 & 3.1 \\ \text { Normal } & 105-154 & 2.8-3.5\end{array}$

Tf phenotypes with Tf alleles $O$ and $R$

$\begin{array}{lcc}\text { Number } & 5 & 5 \\ \text { Range } & 52-96 & 2.8-3.3 \\ \text { Mean } & 71.2 & 3.1 \\ \text { Normal } & 64-93 & 2.8-3.5\end{array}$

Tf heterozygotes with $\mathrm{Tf}$ alleles $\mathrm{D}, \mathrm{F}$ or $\mathrm{H}$ combined with $\mathrm{O}$ or $\mathrm{R}$

$\begin{array}{lcc}\text { Number } & 11 & 10 \\ \text { Range } & 57-92 & 2.7-3.8 \\ \text { Mean } & 74.9 & 3.2 \\ \text { Normal } & 70-90 & 2.8-3.5\end{array}$

(Compared with 30 healthy mares TfFR)

Figure 1 shows scatter diagrams of Tf values related to albumin concentration in sera of 44 horses with Tf alleles $D, F$ and $H$ (A) and in sera of 40 horses with Tf alleles D, F or $H$ combined with $O$ or $R$ (B). 

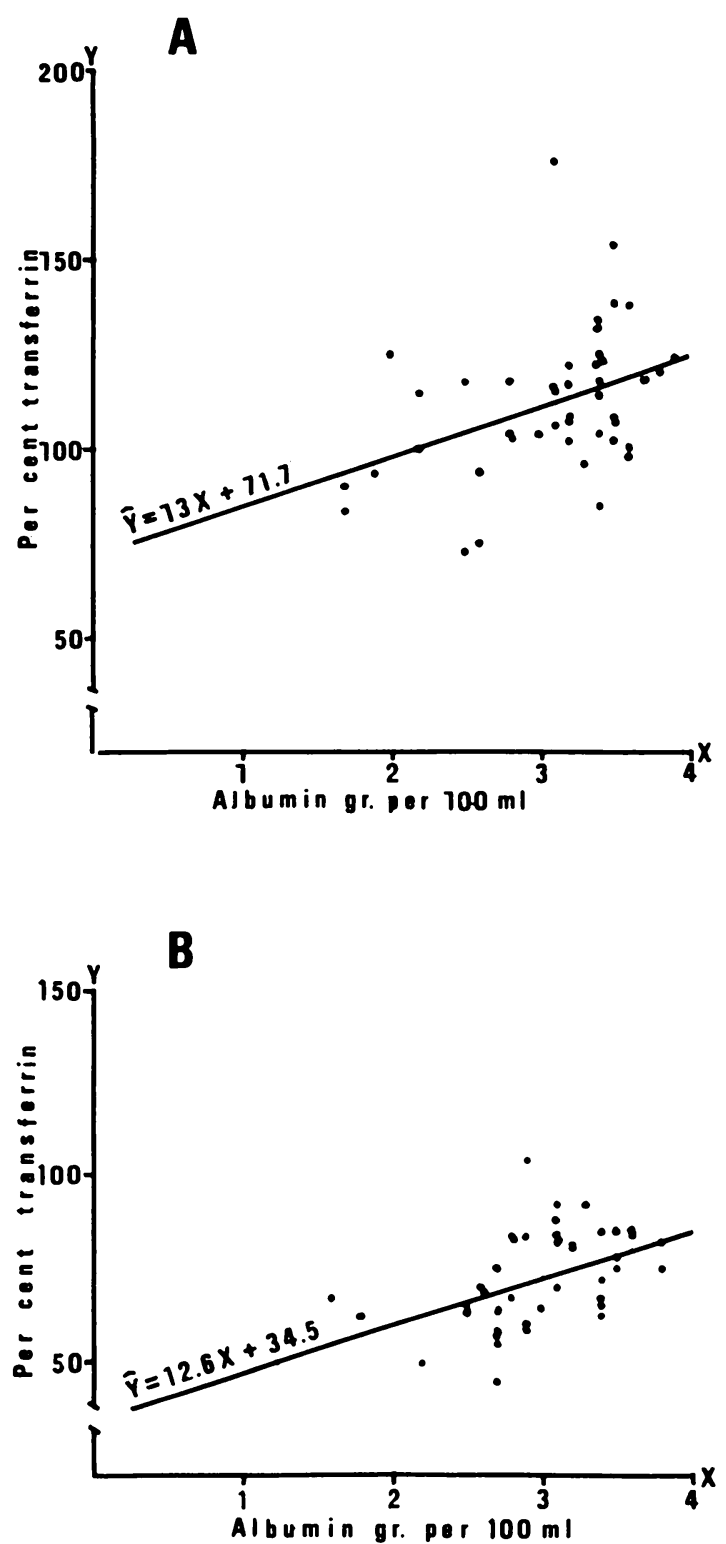

Figure 1. A. A scatter diagram of transferrin values related to albumin concentration in the serum of 44 horses with $\mathrm{Tf}$ alleles $\mathrm{D}$, $\mathrm{F}$ and $\mathrm{H}$.

The correlation coefficient $(r)$ was $r=0.38$. The sample regression equation of $\mathrm{Y}$ on $\mathrm{X}$ was $\mathrm{Y}=13 \mathrm{X}+71.7$.

B. A correspondent diagram of 40 horses with $\mathrm{Tf}$ alleles $\mathrm{D}, \mathrm{F}$ or $\mathrm{H}$ combined with $\mathbf{O}$ or $\mathbf{R}$.

The correlation coefficient was $r=0.47$. The sample regression equation of $\mathrm{Y}$ on $\mathrm{X}$ was $\mathrm{Y}=12.6 \mathrm{X}+34.5$. 


\section{DISCUSSION}

In man, alterations in the serum level of transferrin are associated with many diseases. Low levels have been registered with infections, cirrhosis and starvation, whereas an increase has been seen in patients with iron deficiency anaemia (Giblett 1969). The results of the present work indicate that the equine transferrin reacts in a similar manner as in man during infections, since decreased transferrin levels were found in all $\mathrm{Tf}$ phenotype classes investigated. It has been suggested that transferrin has a bacteriostatic activity due to its successful competition for iron with various microorganisms. By restricting the availability of iron for the microbial metabolism, the transferrins may have an important role in the defence against infections (Aisen \& Listowsky 1980).

In the present material a correlation was found between the Tf value and the serum albumin content. It is known that during inflammatory processes there is an increased diffusion of plasma proteins with low molecular weight such as albumin and transferrin from the blood vessels (Thoren-Tolling 1977). This phenomenon could partly explain the concurrent depletion of albumin and transferrin in serum.

Decreased $\mathrm{Tf}$ values in horses with acute laminitis could be expected, since this condition is connected with an aseptic inflammation in the corium of the hooves. The patient in this group with the lowest $\mathrm{Tf}$ value $(45 \%)$ was in addition suffering from chronic dermatitis, which also may have contributed to the very low transferrin level in serum.

In horses with malignant tumours there was considerable varation in the Tf values among the patients. The horse with a Tf value of $50 \%$ only was a patient having lymphosarcoma associated with a severe monoclonal hypergamma-globulinaemia. In humans, decreased mean level of transferrin has been found in patients with monoclonal immunoglobulinopathies (Wiedermann et al. 1979), and in patients with bowel cancer (Milano et al. 1978). In man also other factors such as malnutrition and anaemia, are believed to influence the serum transferrin level (Milano et al.). It is possible that similar contributing factors may have influenced the transferrin level in horses with malignant tumours in the present material thereby causing the great variation among the animals, although it has to be stressed that there were too few horses in this group to allow decisive conclusions. 


\section{ACKNOWLEDGEMENT}

The author wishes to thank Dr. med. vet. M. Braend, the Department of Internal Medicine I, Veterinary College of Norway, Oslo, for valuable advice and guidance during these investigations.

\section{REFERENCES}

Aisen, Ph. \& I. Listowsky: Iron transport and storage proteins. Ann. Rev. Biochem. 1980, 49, 357-393.

$E k, N .:$ Studies of electrophoresis on cellulose acetate membrane of serum proteins from normal horses, sheep and pigs. Acta vet. scand. 1970, 11, 295-304.

$E k$, N.: Concentration of serum prealbumin ( $\mathrm{Pr}$ ) protein in sick horses and its correlation to blood leucocyte count and albumin content in serum. Acta vet. scand. 1980, 21, 482-497.

$E k, N .:$ Antigen-antibody crossed electrophoretic studies and quantitative comparisons of serum transferrin types in horses. Acta vet. scand. $1981,22,246-259$.

Giblett, E. R.: Genetic Markers in Human Blood. Transferrin. Spottiswoode, Ballantyne and Co. Ltd., London and Colchester 1969.

Kaneko, J. J. \& C. E. Cornelius (eds.): Clinical Biochemistry of Domestic Animals. G. T. Dimopullos: Plasma Proteins. Acad. Press, New York and London 1970.

Milano, G., E. H. Cooper, J. C. Goligher, G. R. Giles \& A. Munro Neville: Serum prealbumin, retinol-binding protein, transferrin and albumin levels in patients with large bowel cancer. J. Natl. Cancer Inst. 1978, 61, 687-692.

Snedecor, G. W. \& W. G. Cochran: Statistical Methods. The Iowa State -University Press, Ames, Iowa, USA 1967.

Thoren-Tolling, $K$. .: Serumproteinvariationer vid patologiska tillstånd hos häst och hund. (Serum protein variations with pathologic conditions in horses and dogs). Svensk Vet.-Tidn. 1977, 29, $917-927$.

Wiedermann, D., B. Wiedermann, K. Cidl \& V. Scudla: Individual serum proteins and acute phase reactans in monoclonal immunoglobulinopathies: Patients with immunoglobulin A myeloma and light chain myeloma. Neoplasma (Bratisl.) 1979, 26, 315324.

\section{SAMMENDRAG}

Konsentrasjon av transferrin i serum hos syke hester og dets forhold til albumin-innhold $i$ serum.

Det ble foretatt en undersökelse av transferrin (Tf) - konsentrasjonen i sera fra syke hester ved hjelp av Mancini's immundiffusjonsteknikk. Relative verdier $i$ forhold til et valgt referanseserum ble bestemt på et totalantall på 112 hester.

Hester med akutte infeksjoner hadde Tf-verdier som var signifikant lavere enn normale dyr. Den laveste individuelle verdi i denne 
gruppen $(46 \%)$ ble funnet hos et 6 måneder gammelt föll med temperatur $41^{\circ} \mathrm{C}$ og vanndig diaré.

Hester med akutt forfangenhet hadde også nedsatte Tf-verdier. Den laveste verdi i hele materialet $(45 \%)$ ble funnet hos en hest som tilhörte denne gruppe.

Det var en positiv korrelasjon mellom Tf-verdien og albumininnholdet i serum.

(Received January 23, 1981).

Reprints may be requested from: Nils Ek, the Department of Internal Medicine I, Veterinary College of Norway, P.O. Box 8146, Dep., Oslo 1, Norway. 